\title{
Protestantism in Postsoviet Russia: An Unacknowledged Triumph
}

\author{
SERGEI FILATOV
}

After ten years of freedom in Russia some of the results of the religious revival there can now be summed up. In assessing which religious movements have achieved the greatest success, from the religious standpoint, there can be only one conclusion the greatest gains, up to the year 2000, have been made by the Protestants.

The basic achievements of the Orthodox Church have been in the ideological, cultural and political sphere. Russian public opinion nowadays shows a great deal of respect for the Orthodox Church. The majority of Russians consider themselves Orthodox. There is hardly any significant anti-Orthodox or anticlerical feeling in the country. In fact, the Orthodox Church has been granted semi-official status. The state authorities make use of the Church's authority in the political struggle. Throughout the country churches are being built and restored from budgets of various sizes, and are also being financed by big business, as a result of direct pressure from the authorities.' However, in the purely religious sphere the success of the Russian Orthodox Church has been far more modest. Surveys show that fewer than five per cent (according to some sources, only two per cent) of the population are practising Orthodox believers. ${ }^{2}$ Communal activities in the parishes are extremely rare. With the rare exception of initiatives taken by individual priests, parishes and monasteries, the social services provided by the Orthodox Church have been even more modest. The Church's intellectual and theological life goes practically unnoticed.

The revival of Islam among traditionally Muslim peoples is similar in character to that of the Orthodox Church among Russians (to some extent some of the peoples of Dagestan are an exception, but their religious identification with Islam is not as great as is generally believed). Much of it is ideological, cultural and political, while the number of practising believers is actually very small. ${ }^{3}$

In the mass media and in political circles there has been much discussion (usually anxious) concerning the growth of new religious movements (the so-called 'totalitarian sects'). By the end of 1999, however, it was quite clear how weak and few in numbers they were, much less widespread than in the West.

Against this background, the relative success of the Protestants appears extremely impressive. In order to understand how much the Protestants have achieved, we should remember what Russian Protestantism was like in the mid-1980s.

At the beginning of the perestroika period Protestantism on the territory of the present Russian Federation consisted of the Evangelical Baptist Churches (in the form of the All-Union Council of Evangelical Christians-Baptists (AUCECB) (Vsesoyuzny soyuz Yevangel'skikh Khristian-Baptistov)) and an illegal organisation, 
the Council of Churches of Evangelical Christians-Baptists (CCECB) (Sovet tserkvei Yevangel'skikh Khristian-Baptistov)), and the Pentecostals and Adventists. Any other Protestant denominations either did not exist at all in Russia or were represented only symbolically.

In most parts of Russia only the AUCECB existed legally, in fact becoming the embodiment of Russian Protestantism. In the 1940s (or in some cases later) the authorities had compelled representatives of various Protestant denominations to join this Union. As a result of this participation in one centralised organisation the AUCECB developed a certain unifying ideology. This ideology had to be sufficiently broadly-based to suit the churches with various different teachings that formed part of the AUCECB. It was formulated and accepted by most leaders of congregations in the Union for many years, from 1944 to the late 1980s.

Certain Baptist tendencies, embodied in the growing importance of the role of the presbyter in the congregation, reached a point at which the organisational centralism typical of an individual Baptist church congregation became a hierarchical system, strictly controlled within an extensive structural framework, characteristic of more traditional Churches. The presbyter took charge of the service on behalf of the congregation and was responsible for congregational activities as a whole. The believers gradually became accustomed to letting the presbyter take charge of everything. Official representatives of the AUCECB (from 1947, senior presbyters (starshiye presvitery)) were established as supervisors of the congregations in each district. Thus a strict hierarchical system was set up within the framework of the Union: senior presbyter-presbyter-deacon. One of the distinguishing features of life among the congregations of the Union was the fact that practically all religious activity was concentrated on the services, which consisted of Bible readings, sermons by the presbyter and celebration of Holy Communion once a month. For the ordinary believer church life consisted of attending church and following evangelical principles in his private life. The presbyter would express support for the Evangelical Christians-Baptists, trying not to raise awkward issues in his sermons (such as predestination, or attitudes to the state, to the Jews, to missionary activity and so on) and would call on believers to consider how far they were inwardly obeying God's commandments. A rapt atmosphere was created by emotional hymn singing, to which a great deal of attention was devoted, and by the reverential setting of the service. The particular Russian form of piety favoured by the Evangelical Christians and Baptists began to develop even before the 1917 Revolution, but it was during the Soviet period that it finally took shape. It has begun to change only since the late 1980s.

The attitude of the Union's leaders to Soviet rule and to the state as a whole was based on impressions formed in the 1920s and 1930s. The Evangelical movement at that time was led by Ivan Prokhanov. From the very start he came to an understanding with the Bolsheviks and tried to see socialism in a Christian context. Prokhanov even had the idea of founding a city where Christian communes might live. (He wanted to name the city Yevangel'sk, but this was unacceptable to the secular authorities, who proposed the name Gorod Solntsa (City of the Sun) instead.) When the authorities began to campaign actively against all religious believers Prokhanov left Russia and stayed abroad. The social evangelism of Prokhanov and other Evangelical Christians was even then becoming intertwined with the Soviet patriotism that had been developing with the AUCECB since the moment it was founded. The general view within the AUCECB was that the first decade of Soviet power had been the best period in the history of the Evangelical movement in Russia, 
which meant that Soviet rule was the most suitable for the Protestants of Russia. In the 1920s the Bolsheviks had indeed created favourable conditions for the development of Protestantism, but later on the hopes of the Evangelical Christians turned out to be unfounded. However, in their official speeches the leaders of the AUCECB still tried to preserve the stereotype of the Protestant 'golden age' of the 1920s and kept on stressing their agreement with the Soviet authorities. At the same time, it cannot be said that all of them were equally well-disposed towards the authorities. Even a registered congregation did not necessarily follow the official line agreed on with them. Few of the congregations that registered and joined the centralised organisation did so because they actually wanted the Soviet authorities to approve both the presbyter and candidates for baptism. According to the strict rules of the AUCECB, adults over 18 could be baptised, but Mikhail Orlov, deputy to the AUCECB president, Yakov Zhidkov, declared that persons who were 18-25 years old were too young and could not comprise the majority of candidates for baptism: this was a stipulation made by the authorities. ${ }^{4}$ Members of these churches generally believed that they could survive legally as a Christian community in their own country and lay down the heavy burden of living an underground, illegal existence. The authorities sometimes broke up even registered congregations, but most church members simply grew accustomed to the fact that the atmosphere surrounding the peaceful services their congregations held was one of constant pressure.

A particular form of Soviet patriotism evolved among the members of congregations belonging to the AUCECB. At first this was in the context of the defence of the Motherland against the enemy during the Second World War, but later it took the form of pride in the power and greatness of the USSR and delight in the open spaces and natural beauty of the country which was the birthplace of Soviet Baptists. Many believers saw wartime military action. President of the AUCECB Yakov Zhidkov, for example, lost two of his sons during the War. The leaders of the AUCECB stressed that the Soviet authorities allowed them to profess their faith. Issues of Bratsky vestnik, the AUCECB journal, made particular reference to the number of nationalities represented in Baptist congregations, emphasising the international nature of the Union as a whole. They reinforced the patriotic feelings of Soviet Baptists and their view that the Soviet authorities had well-intentioned ideals and that the Bolsheviks had initially granted Protestants certain freedoms. In addition, articles by official representatives of the Union expressed the idea that the Lord ruled over all peoples and kingdoms, and had established and preserved the Soviet system in place of 'the prison of nations' that was tsarist Russia. ${ }^{5}$

The Soviet Baptist work ethic followed on smoothly from patriotism. Most ordinary Baptists were ordinary Soviet workers, in factories or on collective farms. Their work ethic held that a sincere love of the Motherland, the land on which they lived (however totalitarian the state itself might be), must be reinforced by honest labour and obedience to government decrees. The classic Protestant work ethic of honest labour carried out in the name of God underwent fundamental changes as part of AUCECB ideology. The idea of labour for the sake of the Motherland, as part of building socialism, began to appear more clearly. This then became the honesty God required from the believer.

Such was the ideology of the AUCECB, to which the vast majority of Russia's Protestants subscribed. The AUCECB's irreconcilable ideological opponent was the Council of Churches of Evangelical Christian Baptists (CCECB) - the initsiativniki (Reform Baptists).

The Reform Baptist movement came into existence in 1961, after some believers 
began to protest against the servile attitude to the authorities adopted by the AUCECB and its renunciation of work with children, missionary activities and an independent internal church life. The initsiativniki were uncompromising in defending their freedom against the totalitarian state. In many ways, however, they were similar to the AUCECB: they rejected secular culture and cut themselves off from it, and their dress and everyday lifestyle were traditionally conservative. State control was replaced by internal church control: the members of a congregation kept an eye on each other, and the pastors of different congregations monitored each other's activities. A specifically Russian form of pietism was probably even more characteristic of the dissidents than of members of the AUCECB.

The Adventists and Pentecostals, though fewer in number, had their own dissidents too. However, the role of Russian Protestantism in the country's religious, political and cultural life was quite marginal: hardly any members of the intelligentsia were Protestants; they were socially and culturally passive.

After the fall of communism, however, this situation began to change rapidly. There is a history of centrifugal tendencies among the Evangelicals and Baptists worldwide. Radical movements have come and gone. Most of these never existed in Russia. However, evangelical movements now arose within the AUCECB (renamed the Russian Union of Evangelical Christians-Baptists (RUECB) (Rossiisky soyuz Yevangel'skikh Khristian-Baptistov) in 1991). Their members called for more social and sometimes even political involvement, showing an interest in coming to grips with secular culture. Hitherto the Baptists had been indifferent to dogmatic disputes, but this now began to change: principled Calvinists and Arminians began to appear. Within the RUECB itself there was growing dissatisfaction with its excessive centralisation, paternalism, passivity and servility. Congregations began to leave the Union in large numbers. The Union's leadership introduced organisational reform, cutting down on centralisation and allowing a wider range of opinion. The exodus of congregations was halted, but despite this, by 1999 a number of new associations of Baptists and Evangelicals had emerged. These included congregations that had left the RUECB or the CCECB, as well as formerly independent congregations and some founded by western missionaries. These do not have to carry the burden of the Soviet past and have injected something basically new into Russian Protestantism.

In this context, special mention should be made of the Christian Missionary Union (CMU) (Khristiansky missionersky soyuz) and the Association of Churches of Evangelical Christians (ACEC) (Assosiatsiya tserkvei Yevangel'skikh Khristian).

The CMU, which came into existence in 1994, has absorbed a number of independent churches that once belonged to the RUECB or the CCECB. It is a religious movement that is basically different from all that was part of Russian Protestantism under Soviet rule. It takes no view on the various different styles of worship of its member churches and concentrates on missionary activity and evangelisation. It works mainly among young people and the intelligentsia. The CMU missionaries make use of some elements of today's youth culture and of the national culture of the minorities among whom they work. They are stepping up their charitable activities, not only among fellow-believers, but also among the wider population.

The CMU has evolved out of the Russian Baptist movement itself; but recently evangelical movements introduced to Russia by western missionaries have begun to take root. Perhaps the most important movement of this kind is the ACEC, which came into existence in 1998 as a result of well-planned missionary activity by the American organisation East-West Ministries. In the USA this church association would not be anything unusual. Its ideology is of a conservative, even funda- 
mentalist, Calvinist Baptist kind, but it also takes up a position of principled support for democracy and respect for the law. The number of congregations joining the ACEC is increasingly remarkably quickly throughout the country. What is also striking is that unlike traditional Russian Churches it includes a relatively large number of people from the intelligentsia, and the spiritual leader of the ACEC is now a former Moscow University professor, Nikolai Karchazhkin.

In recent years, then, the Baptist-Evangelical movement has seen considerable evolution and growth. The same could be said, to an even greater extent, of the Pentecostal movement. By 1999 the Pentecostals had overtaken the Evangelical Baptists in numbers and in the variety of movements within their Church.

Under Soviet rule there was only one Pentecostal association, leading an illegal existence - the United Church of Christians of the Evangelical Faith (Ob"yedinennaya tserkov' khristian very yevangel'skoi), led by the courageous prisoner of conscience Ivan Fedotov. Until perestroika it consisted of a few dozen small congregations. In the ideological and social sense Fedotov's association was a direct parallel to the Baptists' Council of Churches.

In 1985 almost all the Pentecostal congregations in the AUCECB immediately left it and united with certain autonomous congregations (including unregistered ones) to found their own independent union - the Russian Union of Christians of the Evangelical Faith (Rossiisky soyuz khristian very yevangel'skoi), led by Vladimir Murza. As religious freedom took hold the activities of this Union took on a phenomenal dynamism.

Besides these two Pentecostal organisations independent Pentecostal congregations began to appear all over Russia, largely as a result of Ukrainian, American and Western European missionary activity.

A completely new phenomenon was the appearance of congregations of a charismatic type. These are by now predominant in the Russian Pentecostal movement. The dynamic charismatic movement has radically transformed the public image of Russian Pentecostalism. It has attracted many socially active young people to the Church. Certain Pentecostal Churches - such as New Generation (Novoye pokoleniye) in Yaroslavl' or the Vineyard (Vinogradnik) congregations in a number of Siberian towns - have many educated young people among their members. This is something completely new in the Russian Pentecostal Church.

In many regions of Russia the charismatic churches have started organising ecumenical associations of religious minorities, opposing violations of freedom of conscience. Many charismatic churches have begun to take an active part in political life; in some regions, such as Khakasia, Udmurtia, Sverdlovsk, Omsk and Yaroslavl', united and well-organised political activity by the charismatic Pentecostals has become a significant factor in local political life. Pentecostals (including charismatics) are widely acknowledged as leaders in the field of charitable activity and social work.

The charismatic movement is arousing increasing dissatisfaction among traditional Pentecostals who do not like its informal and emotional services and some of the types of social activity it is involved in. Feelings of this kind have become more intense since the law on freedom of conscience was adopted in 1997. In practice this law has forced many autonomous charismatic churches to join large centralised religious associations. The charismatic Pentecostal churches had only two choices: the Church of God (Tserkov' Bozhiya) (later called the United Association of Christians of the Evangelical Faith (Pentecostals) (Ob"yedinenny soyuz KhVEP)), which was founded in 1990 by Pastor Sergei Ryakhovsky, and in which the charis- 
matic tendency is completely dominant; and the more traditional Union of Christians of the Evangelical Christian Faith (Pentecostals) (Soyuz KhVEP), led by Murza. For various reasons many charismatic churches joined Murza's Union rather than Ryakhovsky's United Association, and now have more influence within the Union than the traditionalists. Since 1999 a group of traditionalist pastors have united to oppose the charismatics' influence in Murza's Union, but this is the last stand of the defeated. In both legal Pentecostal unions the charismatic movement, ideologically and psychologically close to western, American Pentecostalism, is now predominant. The last bastion of traditional Pentecostalism is the United Church (Ob' 'yedinennaya tserkov'), led by Ivan Fedotov, which refuses to register with the state on principle.

The churches and congregations which are members of the two legal Pentecostal unions are the most rapidly growing Christian denominations, represented in all districts of Russia; their influence is spreading beyond the local capitals and even into rural areas as they constantly expand their missionary activity among all social classes and many of Russia's national minorities (including those that are traditionally Muslim or Buddhist).

If the Pentecostal Church was represented at least in a small way before 1991 on the territory of present-day Russia, the Lutheran and Methodist Churches hardly existed at all 10 years ago; but now they are expanding rapidly.

Until the start of perestroika the Lutheran Church was officially regarded as the religion of most Russian Germans; the Latvian Bishop Haralds Kalnins had managed to compile lists of 'Lutheran' congregations, which he officially supervised. In fact, the 'Lutheran' German congregations were far from being Lutheran; historically, even before the Revolution, the great majority had been dissident Pietist congregations trying to free themselves from the control of the official Lutheran clergymen imposed on them by the tsarist authorities. By liquidating the Russian Lutheran Church the Soviet authorities succeeded only in creating favourable conditions for movements that had already existed before the Revolution: most of the Germans 'Lutherans' in Russia became Baptists or members of the so-called Lutheran 'congregations of brethren' ('bratskiye obshchiny'), which in reality hardly differed, as far as their teachings or religious identity were concerned, from the more conservative Baptists. ${ }^{6}$

In 1994 an Evangelical Lutheran Church (ELC) was founded in Russia, Ukraine, Kazakhstan and Central Asia, with its centre in St Petersburg, directly backed and supported financially and administratively by the German Lutheran Church and the West German government. Pressure from the West Germans led to a German citizen, Bishop Georg Kretschmar, becoming head of the Church and clergymen from West Germany being appointed to almost all leading positions. One of the Church's main tasks was to organise the national and cultural life of Russian Germans. The ELC was supposed to promote the social policy of the German government by discouraging German emigration from Russia. However, by 1999 it was already clear that these plans had failed.

Liberal theology and a centralised, bureaucratic church organisation turned out to be quite alien to most of the conservative and democratically-inclined Russian German 'Lutherans'. After a short struggle for power (1994-97), the Russian German pastors were rebuffed and only a small number of Russian Germans, who had preserved their faith but who were still extremely dissatisfied with the clergy from Germany and at loggerheads with them, stayed on as parishioners of the ELC.

However, the ELC was not left without a flock. A small but influential section of its parishioners was made up of Russian Germans who had returned to the faith 
after perestroika and found their home in the ELC largely for national, cultural and ideological reasons. A more important and significant phenomenon was the fact that ELC parishes attracted Russian intellectuals and young people with liberal views. Russians now clearly form the majority in ELC parishes in some cities - for example Arkhangel'sk, Yaroslavl', Ul'yanovsk, Krasnoyarsk and Kazan' (and the latter even includes Tartars as well). Some of these young Russian intellectuals are training as pastors, and will eventually take over from the German pastors. The ELC is fast becoming a Church of Russians, besides being one of only two Churches with a liberal theological viewpoint (the other being the United Methodist Church).

The ELC is not the only Lutheran Church to appeal successfully to Russians. It has conservative rivals: the Church of Ingria and the Biblical Lutheran Church. These are officially under the jurisdiction of the Estonian Lutheran Church.

The Church of Ingria originally came into being in the late 1980s and early 1990s as the revived Lutheran Church of the native Finnish-speaking population of the Leningrad region and some of the surrounding districts. Lutheranism among the inhabitants of Ingermanland had been completely wiped out under Soviet rule and in fact was nonexistent when it was revived. The officially independent Evangelical Lutheran Church of Ingria was founded in 1991. From the very start the pastors of the Church of Ingria did not limit themselves to missionary activities among the people of Ingermanland. Russians also began to join the Church; large, exclusively Russian congregations came into existence in St Petersburg, Moscow, Nizhny Novgorod, Voronezh and some other cities. The Church's missionaries have also achieved successes working among the Finnish-speaking peoples of the Volga Region and the north-eastern European part of Russia who have never been Lutherans - the Mordvinians, Udmurts, Mari and Komi. A significant number of Russians have also joined the parishes formed among these nationalities. In Siberia, the Biblical Lutheran Church, which has a wholly Russian image, has become a counterpart to the Church of Ingria: by 1999 it had a number of large parishes consisting of educated young people. Both these conservative Lutheran Churches receive a significant amount of financial and organisational support from the Lutheran Church of the Missouri Synod, and this goes a long way towards explaining their success. ${ }^{\text {? }}$

There used to be no such thing as Russian Lutheranism, but now it is becoming a widespread phenomenon in various parts of Russia. However, an equally important phenomenon over the last ten years has been the growth of the Russian Methodist Church.

The pre-Soviet history of Methodism is that of a few Methodist congregations which were formed shortly before and after the Revolution and which survived for only a few years before being liquidated in the 1920 s. One could indeed say that until recently there has been no such thing as Methodism in Russia. The recent rapid expansion of the Methodist Church in Russia is therefore impressive.

The United Methodist Church (UMC) first established contacts in Russia at the time of perestroika, originally through Methodists in the Baltic States and Korea; since 1989 links have been made with American Methodists as well. From the very start the UMC tried to achieve official recognition in Russia, operating through the Soviet Peace Fund, but at first its missionaries did not found congregations, limiting themselves to providing material aid and giving lectures on the Bible. The situation changed after the 1991 coup. The UMC established itself in Russia as a religious organisation rather than as a charity. The basic principle of Methodist missionary work has always been to reject mass evangelisation in favour of close personal 
contacts with serious Bible study for anyone interested.

Their first important move was to reach an agreement with the Peace Fund to found Russian Initiative (Rossiiskaya initsiativa); this established partnerships between Methodist churches in America and cities or regions in Russia. The first step in this partnership was assistance to children's homes and other social work. It was only later that American missionaries appeared and lectures on religious history and English language courses were organised; actual religious teaching began as well. Bible study groups were formed in various cities; their aim was to let people learn about Christianity for themselves, so that they would understand that faith was something personal, not just a matter of group identity. Methodism was presented at these meetings as one of the ways in which the faith was formulated. If groups took the initiative, expressing a wish to convert to Methodism, a pastor was sent out to them, who would then found a church.

The UMC did not limit itself to acting through the Peace Fund, however. This process of building up congregations was only one of the methods used. Most churches were founded through the personal witness of missionaries and initiatives taken by Russian citizens themselves. In the Moscow area, for example, only one out of 20 churches was set up wholly through the Peace Fund. In 1992 the Russian United Methodist Church (RUMC) (Rossiiskaya ob' 'yedinennaya Metoditskaya tserkov') was founded; a number of churches had already been registered in 1991 .

Methodism has spread far and wide during the 1990s and Methodist congregations are scattered all over Russian territory. Church meetings are informal in style: participants discuss the Bible, drink tea together and sing hymns they have composed. One of the reasons for the rapid expansion of Methodism is the moderation and flexibility of its ideological principles, as well as the 'spirit of freedom' that reigns in this Church. With its emphasis on freedom and service the UMC is one of the most liberal and democratic Churches. It is the only major Church in Russia to adopt a liberal position on the question of homosexuality. The ordination of women has become a way of openly demonstrating the principle of equality of all individuals before God. The RUMC is the first Church in Russia to have female pastors, and they now comprise almost half of the clergy. Not all members of the Church are in favour of this, but no open opposition has been observed, as the pastors are selected by the congregations themselves.

The RUMC works actively with alcoholics and drug addicts and runs its own charitable organisations. Almost every congregation works with clinics and societies for the disabled. Social centres have also been founded entirely by the Methodists; one of the largest of these is the International Humanitarian Centre (Mezhnatsional'ny gumanitarny tsentr) for the rehabilitation of drug addicts and alcoholics in Voronezh.

The Church's main priority is education work, however. The RUMC has always sponsored foreign language courses. Church members give lectures on the Bible and the history of religion in schools and colleges, as the congregation in the Moscow district of Perovo does, or in the evenings in clubs and churches. Methodists believe that through education people can help themselves to develop and improve and then later help others. The most important Methodist principle, enunciated by Wesley himself, is the path to perfection, which, like 'sainthood', is both a spiritual and a social concept.

The Methodist Church in Russia attracts a large number of educated people and their involvement has given the Church quite a high public profile. They are attracted by the idea of combining the Bible with reason and by the Methodists' belief in the 
intellectual progress of mankind under the guidance of God.

Methodism is a denomination imported from abroad, but it is now trying to become Russian and to find its 'roots' in Russian history and culture. Russian Methodists regard the Archpriest Avvakum as a model of the true Christian. They find elements of their own teachings in the works of Khomyakov, Berdyayev and Solov'yev. All this throws an interesting light on the question of patriotism. Even at this early stage of the development of Methodism in Russia a 'patriotic' element has already appeared, urging greater independence for the RUMC and the selection of a Russian bishop as soon as possible. ${ }^{8}$

It seems that Russia today stands in need of Methodist principles if the emergence and widespread growth of an authentically Russian religious movement, Ethical Behaviour (Etika povedeniya), is anything to go by. The leaders of this movement first heard of Wesley's teachings from the author of this article: nevertheless the doctrine and religious practice of Ethical Behaviour are similar if not identical to the principles and basic ideas of Methodism.

Ethical Behaviour started in Novosibirsk in the early 1990s and by the end of the decade it had already set up over 100 clubs (as the members call their communities). It started with the religious quest of a Novosibirsk school teacher, Sergei Ustyuzhanin. In 1990 he went through a severe crisis, when life seemed meaningless, and came close to suicide. At the worst moment of this crisis he sensed the presence of God, and he believes that he received the gift of true insight. He began to receive 'messages from above'. The main revelation was that of his own sinfulness, and the need for him to repent and completely reform. He realised that all human beings are sinful, and the next 'message from above' showed him that he must found clubs, where he would teach people the truths he had received. He acquired the 'gift of conviction'.

At first Ustyuzhanin thought of himself as a member of the Orthodox Church. In 1990 he was baptised by the well-known liberal Siberian priest Boris Pivovarov. Members of the first two clubs he founded in 1990-92 regularly attended Orthodox services. However, he gradually became estranged from the Orthodox Church, which he saw as permeated with corruption, commercial interests and formalism, and he was soon criticising the 'theatrical' nature of the Byzantine liturgy and the use of icons. He already had his own ideas before he entered the Orthodox Church, where he was to remain for a short time only.

Almost all his followers were nonbelievers before their conversion. They have been working out the doctrines of Ethical Behaviour as if Christianity had had no history before they came along and as if they were the first people to open the Bible. Their ideology includes thoroughly fundamentalist Protestant ideas alongside concepts that go well beyond the limits of Christianity: Ustyuzhanin, for example, believes in the possibility of reincarnation. The doctrines are still in a state of development and basic principles are liable to change before one's eyes.

Ustyuzhanin and his followers are not greatly concerned, however, with theological speculation. They are basically interested in how man can achieve perfection, in repentance, in overcoming sin and in getting closer to God. As in Methodist teachings, salvation is seen as the work of God and man combined. The human being rejects sin, while God helps him to take each subsequent step. Man's task is to overcome his sinfulness, to 'reach the place from which Adam and Eve were expelled', to achieve 'sainthood'.

One of the basic concepts in Ustyuzhanin's theology is 'consciousness' ('soznaniye'). Consciousness comes into being only after sin is rejected, otherwise it is 'semi-consciousness'. When a man is saved from sin physiological changes take 
place within his nervous system, and the flesh is transformed. To someone who has truly repented and rejected sin, God imparts spiritual gifts. After receiving these gifts a person is capable of passing them on to others through the laying-on of hands. Ustyuzhanin is convinced that he once passed them on to an entire class of schoolchildren whom he was teaching.

Ethical Behaviour makes a clear distinction between 'religion' and 'faith'. Religion means ritual and formalism; it has no meaning and does not bring man closer to God. Faith must be conscious, based on reflection, on a personal search for Truth; it must lead to repentance and reform. Blind faith must be resisted.

Ustyuzhanin is completely opposed to music, singing or any artistic shaping of club meetings. Repentance must be sincere and absolutely free. An individual must recall the sins he has committed, acknowledge them and repent, praying 'Lord, I beg you to forgive me this sin. Please help me not to commit it again.'

The movement has drawn up a detailed list of some 200 sins or ethical violations, and has worked out refined methods of overcoming them. At meetings participants are divided into 'active members' and 'visitors'. The 'active members' are people 'who have no obvious sins', who have learned the basic principles and methods of the movement and believe they have received a gift from above. All the movement's activities are free of charge. Most of Ustyuzhanin's followers are impoverished or unemployed intellectuals - teachers, doctors, engineers.

After the collapse of the Soviet Union there was a wide consensus among religious believers and secular observers that the ideological vacuum left after the fall of communism would soon be filled by reborn faith. Time proved them wrong: Russia is still one of the most secularised countries in the world, if not the most secularised. The successes of the Orthodox, of Protestantism, Catholicism, Islam and the new religious movements are much more modest than hoped for in the late 1980s. Nevertheless, against this generally modest background the successes of Protestantism stand out as particularly significant. It is already clear that a wide variety of Protestant denominations have not only taken hold in Russia but have struck roots in Russian soil. In this short survey I have been able to touch on only the most significant phenomena. In the course of ten years a substantial Protestant intelligentsia has appeared out of nothing. Protestants now play a significant role in public life, charitable work and human rights work. In certain regions Protestant associations are participating effectively in political life.

In conclusion, it is worth mentioning again one feature of the dynamic intellectual life of Russian Protestantism: many Protestant movements are actively searching for roots in the history, culture and spiritual life of Russia, and trying to discover features they share with Russian Orthodoxy. Some Pentecostal groups have created a legendary history for themselves, going back to the time of Princess Ol'ga; the Christian Missionary Union gives sermons on the Protestant tradition in Russian Orthodoxy, represented (amongst others) by St Sergi of Radonezh, Filipp Kolychev and Fr Aleksandr Men'; the Lutherans of the Church of Ingria and the Lutheran Biblical Church in Siberia are adapting parts of the Orthodox liturgy for their own use. Protestantism in Russia is not just growing, it is also becoming more and more Russian.

\section{Notes and References}

1 Sergei Filatov, 'Novoye rozhdeniye staroi idei: pravoslaviye kak natsional'ny simvol', Politischeskiye issledovaniya, no. 3, 1999, pp. 138-49. 
2 K. Kaariainen and D. Furman, 'Veruyushchiye, ateisty i prochiye (Evolyutsiya rossiiskoi religioznosti)', Voprosy filosofii, no. 6, 1997.

3 Sergei Filatov, 'Religion, power and nationhood in sovereign Bashkortostan', Religion State and Society, vol. 25, no. 3, 1997, pp. 268-80; id. 'Tatarstan: at the crossroads of Islam and Orthodoxy', Religion State and Society, vol. 26, nos. 3/4, 1998, pp. 265-77.

4 V. Zavatsky, Yevangelicheskoye dvizheniye v SSSR posle vtoroi mirovoi voiny (Moscow, 1995), p. 80.

3 Yakov Zhidkov, Bratsky vestnik, no. 4, 1947, pp. 5-6.

- Gerd Stricker, 'Lutheraner in Sibirien', Glaube in der 2 Welt, nos. 7/8, 1998, pp. 34-41.

' Xenia Dennen, 'Lutherans in Russia', Keston News Service, 29 May 1998.

s Roman Lunkin, 'Methodists discuss selection of bishop', Keston News Service, 9 July 1999.

(Translated from the Russian by Marite Sapiets) 